\title{
Gallbladder Ascariasis: A Case Report and Review of the Literature
}

\author{
Safra Kesesi Askariazisi: \\ Olgu Sunumu ve Literatürün Gözden Geçirilmesi \\ Ogün Taydaş ${ }^{1}$, Mustafa Özdemir ${ }^{2}$, Behiç Akyüz $z^{3}$, Onur Taydaş ${ }^{4}$ \\ ${ }^{1}$ Sağlhk Bilimleri Üniversitesi İstanbul Haydarpaşa Numune Eğitim ve Araştırma Hastanesi Aile Hekimliği Kliniği, İstanbul \\ ${ }^{2}$ Kayseri Şehir Hastanesi Radyoloji Kliniği, Kayseri \\ ${ }^{3}$ Gölcük Necati Çelik Devlet Hastanesi Radyoloji Kliniği, Kocaeli \\ ${ }^{4}$ Erzincan Binali Yıldırım Üniversitesi Tip Fakültesi Radyoloji Anabilim Dalı, Erzincan \\ Yazışma Adresi / Correspondence: \\ Onur Taydaș \\ Erzincan Binali Yıldırım Üniversitesi Tip Fakültesi Radyoloji Anabilim Dalı, Erzincan \\ T: +905469365473 E-mail: taydasonur@gmail.com \\ Geliş Tarihi / Received : 07.02.2019 Kabul Tarihi / Accepted : 01.03.2019
}

Abstract

Ascariasis is a common parasitic infection caused by ascaris lumbricoides infestation. Although it is mostly seen in the intestines, it may occasionally be seen in the gallbladder. It generally presents with symptoms of right upper quadrant pain. Radiological imaging is very useful in diagnosis. Albendezol or mebendazole may be used in treatment. The case is here presented of a 22-year old male patient radiologically diagnosed with gallbladder ascariasis. ( Sakarya Med J 2019, 9(1):175-179)

Key Words gallbladder; ascariasis; ultrasonography; radiology

$\ddot{O z}$

Askariyazis, Ascaris lumbricoides enfestasyonu nedeniyle oluşan ve sık görülen bir parazit enfeksiyonudur. Çoğunlukla bağı̆rsaklarda görülmekle birlikte nadiren de olsa safra kesesinde de görülebilir. Genelde sağ üst kadran ağrısı ile semptom verir. Tanıda radyolojik görüntüleme oldukça faydalıdır. Tedavide albendezol veya mebendazol kullanılabilir. Bu çalısmada 22 yașında bir erkek hasta sunularak safra kesesi askariyazisinin radyolojik bulguları özetlenmistir.

(Sakarya Tip Dergisi 2019, 9(1):175-179)

safra kesesi; askariyazis; ultrasonografi; radyoloji 


\section{INTRODUCTION}

Ascaris lumbricoides as a member of the ascaridia group is known to be the largest nematode in humans. Ascariasis, which is a frequent parasitic infestation of the hepatic and extrahepatic biliary tree, is more common in tropical regions with poor hygiene conditions, but is also seen worldwide. It has been reported that $25 \%$ of the global population is infected. ${ }^{1}$ Ascaris eggs are usually transmitted to children while they are playing with soil. In adults, transmission may be through eating raw vegetables contaminated with sewage water. They can remain intact in the soil for up to ten years but die within minutes in boiling water. Raw cucumber is the main transmission path of ascaris eggs. In dry and windy weather, the eggs can be transferred in the air in regions where they are endemic. ${ }^{2}$

These white-colored adult parasites live and reproduce in the small intestine lumen, especially in the jejunum. Female parasites have the capacity to release more than 200 thousand eggs per day. Eggs that are ingested orally begin to dissolve in the stomach and are released as larvae in the duodenum. The larvae are $250 \mu \mathrm{m}$ in size in the intestine, and penetrate into the liver through the portal system into the liver, causing milimetric mucosal bleeding at the point of penetration. The remaining larvae fail to fully penetrate and cause an inflammatory response in the intestinal wall, initiated by eosinophils and macrophages. The larvae reach the liver where they die and start a granulomatous reaction in the liver. The presence of larvae in the bloodstream causes peripheral eosinophilia. Some larvae reach the heart and lungs via the hepatic veins, while others reach the lungs through the ductus thoracicus using intestinal lymphatics. The larvae in the lungs pass through the capillary wall and into the alveolar space. The larvae in the bronchial tree are now very large and are ingested from the larynx and hypopharynx. Ascaris infestation into the gallbladder is rare and occurs in only $2.1 \%$ of biliary ascariasis cases. Gallbladder ascariasis is usually associated with an intense intestinal parasitic load. ${ }^{3}$
Radiology has an important role in the diagnosis. Real-time examination of ultrasound (US) in particular can show the movements of parasites. In addition, high-resolution magnetic resonance imaging (MRI) can be used for diagnosis. 4 The aim of this paper was to summarize the radiological findings of ascariasis in a patient with ascaris in the gallbladder.

\section{CASE REPORT}

A 22-year old male with no history of any chronic disease was admitted to our hospital with progressive distension and right upper quadrant pain ongoing for 3 weeks. There was no history of fever, vomiting, nausea, abdominal trauma, weight loss or jaundice, and there had been no similar episode in the past. The family history showed no gastrointestinal cancer. On physical examination, there was mild tenderness over the right upper quadrant of the abdomen and the body temperature and other vital signs were normal. There was no abnormality in the complete blood count. However, mild eosinophilia was noticed in the peripheral blood smear. The serum CRP, sedimentation, ALT, AST, GGT and ALP values were within normal limits.

The patient was referred to the Radiology Unit for further evaluation. On US, an echogenic structure similar to a spider's web was observed in the gallbladder. Strip-like tubular structures with no acoustic shadowing were also observed in the gallbladder (Figure 1). During the examination, these structures were seen to be mobile. The patient was applied with MRI for further evaluation. On MRI, similar to US, hypointense, linear strips were observed in the gallbladder (Figure 2). From these findings, the patient was diagnosed with gallbladder ascariasis. The diagnosis was confirmed by the presence of parasitic eggs in the stool examination.

Albendazole treatment was started and a follow-up examination was made after 15 days. Eosinophilia was seen to have returned to normal at that time and the US findings 


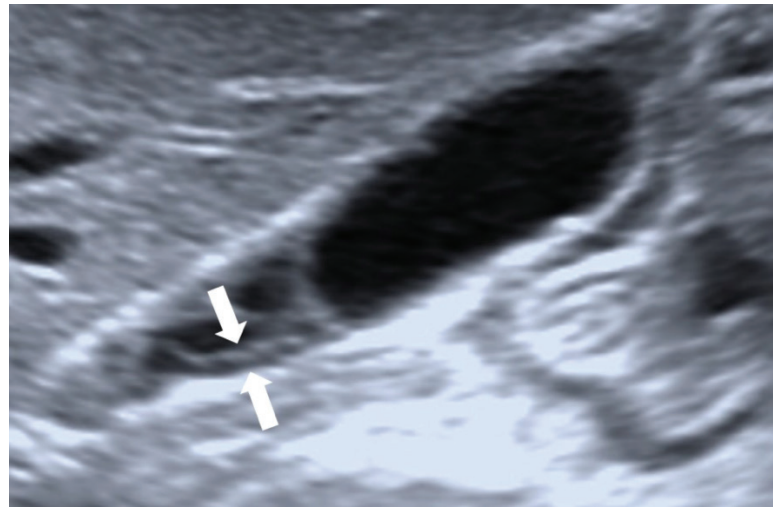

Figure 1: Ultrasonography (US) image showing structures (arrows) with hypoechogenic central and hyperechogenic edges with no acoustic shadow in the gallbladder suggesting ascariasis

of the previous examinations were also lost.

\section{DISCUSSION}

The adult ascaris is usually found in the jejunum, but from there it can move into the duodenum and pass into the biliary area via the ampulla. In this way, ascaris coming from the intestine into the biliary system brings with it the intestinal flora and thus the appropriate factors for cholangitis and cholecystitis are transferred to the biliary system. The presence of ascaris in the biliary tree is manifested in various ways. The most common of these is colic-type right upper quadrant pain. This pain may be accompanied by fever, nausea and vomiting. This table is similar to cholecystitis and the examination shows tenderness in the right upper quadrant. The current patient had similar complaints and right upper quadrant sensitivity. The parasite can cause biliary stasis by causing Oddi spasm with the chemicals it secretes, or by a mechanical occlusive effect. Depending on this stasis, pyogenic cholangitis, cholecystitis and pancreatitis may develop in the patient. ${ }^{5}$

The presence of ascaris in the biliary tract disrupts bile flow and provides a suitable environment for gallstone formation. The obstruction of the bile ducts continues as long as the ascaris remains in the biliary tract. ${ }^{6}$ The $ß$-glucuro-

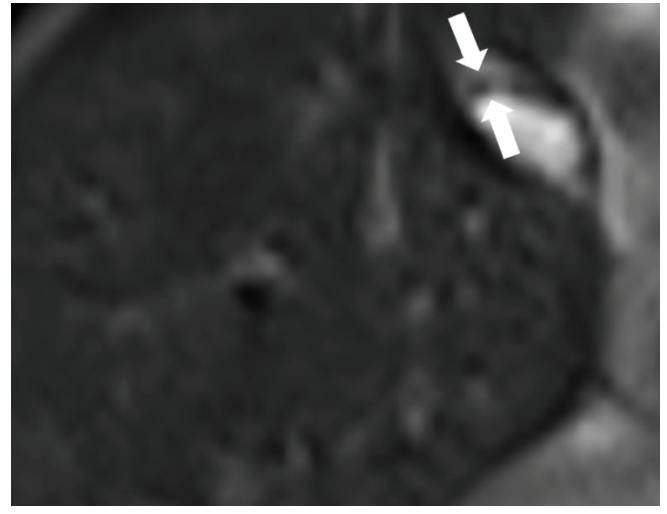

Figure 2: T2-weighted axial magnetic resonance image showing a linear, hypointense band in the gallbladder (arrows).

nidase enzyme produced by ascaris converts soluble bilirubin into insoluble free bilirubin through hydrolysis. This also precipitates as calcium bilirubinate. In this way, intra and extrahepatic stone formation begins. The death or loss of integrity of ascaris in the biliary canal causes a fibromatous reaction with exudation and sudden eosinophil increase, and destruction of the ductal mucosa. A fibrous tissue reaction of plasma cells and other inflammatory cells occurs, resulting in the development of calcification focus and stricture around the broken ascaris and ascaris eggs. Cholangitis may also occur with an infection added to this formation. ${ }^{6}$

The first step in diagnosis is suspicion of biliary ascariasis in patients living in endemic regions who present with biliary symptoms. The presence of ascaris eggs in the bile sample is a definitive diagnosis. However, because this is not possible in many patients, radiological imaging methods are very useful in diagnosis. As one of the commonly used radiological imaging techniques, US has the advantages of being non-invasive, easy to implement and it allows real-time examination. The anatomic position, mobility and number of ascari can be determined with US. In addition, the status of the intra and extra-hepatic biliary tract can be evaluated. On US, when ascaris is viewed along its 
long axis, it appears hypoechoic in the midline, hyperechogenic at the edges, and as a linear strip with no acoustic shadow. ${ }^{7}$ If displayed transversely in dilated biliary tracts, it creates a bulls-eye appearance. There are many findings identified with US for ascaris. The non-shadowing echogenic strip and anechoic tube appearance are important diagnostic indicators. In the current patient, there were linear structures in the gallbladder that were observed to be mobile during the examination. Other characteristic US findings are spaghetti-like, impacted worm sign, and a double-tube image. ${ }^{8}$ When present in an intense form in the biliary tract, it may give an amorphous, hyperechogenic pseudodotumor image. ${ }^{9}$ On computed tomography (CT), it is not usually possible to see the parasite on a single slice. Small parts may appear on multiple slices, and the bulls-eye appearance can also be seen on CT. An advantage of CT over US is that good evaluation can be made of hepatic parenchyma, such as bile ducts. Therefore, CT is useful in diagnosing complications rather than ascariasis. ${ }^{4}$ Magnetic resonance imaging (MRI) and magnetic resonance cholangiopancreatography (MRCP) can be used as an alternative in the diagnosis of biliary ascariasis. MRI has become the gold standard for biliary system imaging, especially because it is non-invasive and allows for $3 \mathrm{D}$ imaging. Ascaris is typically seen as a linear filling defect on MRCP. MRI images of the current patient showed a linear filling defect in the gallbladder. The double-tube and eyeglass sign similar to the findings described in US and CT examinations can also be observed on MRI., 7

Primary treatment of biliary ascariasis is a conservative approach. With the oral administration of anti-helmintics, ascaris should be excreted. Biliary ascariasis usually responds well to conservative treatment. The most commonly used anti-helmintic agents are albendazole and mebeandazole from the benzimidazole group. If there is no improvement in the patient's clinical findings after medical treatment, or if it appears that the ascaris observed on US in the biliary canal is still immobilized (for approximately 10 days) then the ascaris should be removed with endos- copic retrograde cholangiopancreatography (ERCP).10 In the current patient, the symptoms disappeared after treatment with albendazole, and there was no further evidence on US suggesting ascaris. Therefore, ERCP was not performed.

In conclusion, although gallbladder ascariasis is a rare disease, it should be kept in mind in patients with biliary symptoms and the importance of radiology in its diagnosis should not be overlooked.

\section{Conflict of Interest}

The authors have no conflicts of interest to declare.

\section{Financial Disclosure}

The authors declared that this study has received no financial support. 
Sakarya Med J 2019;9(1):175-179

\section{References}

1. Khuroo MS, Rather AA, Khuroo NS, Khuroo MS, Hepatobiliary and pancreatic ascariasis. World J Gastroenterol. 2016; 22: 7507-17.

2. Khuroo MS, Zargar SA, Mahajan R, Hepatobiliary and pancreatic ascariasis in India. Lancet. 1990; 335: 1503-6.

3. Bethony J, Brooker S, Albonico M, Geiger SM, Loukas A, Diemert D, Hotez PJ, Soil-transmitted helminth infections: ascariasis, trichuriasis, and hookworm. Lancet. 2006; 367: 1521-32.

4. Das CJ, Kumar J, Debnath J, Chaudhry A, Imaging of ascariasis. Australas Radiol. 2007; 51: 500-6.

5. Javid G, Wani N, Gulzar GM, Javid O, Khan B, Shah A, Gallbladder ascariasis: presentation and management. Br J Surg. 1999; 86: 1526-7.
6. Shah OJ, Zargar SA, Robbani I, Biliary ascariasis: a review. World J Surg. 2006; 30: 1500-6.

7. Catalano OA, Sahani DV, Forcione DG, Czermak B, Liu CH, Soricelli A, Arellano RS Muller PR, Hahn PF, Biliary infections: spectrum of imaging findings and management. Radiographics. 2009; 29: 2059-80.

8. Khuroo MS, Zargar SA, Mahajan R, Bhat RL, Javid G, Sonographic appearances in biliary ascariasis. Gastroenterology. 1987; 93: 267-72.

9. Schulman A, Ultrasound appearances of intra- and extrahepatic biliary ascariasis. Abdom Imaging. 1998; 23: 60-6.

10. Rana SS, Bhasin DK, Nanda M, Singh K, Parasitic infestations of the biliary tract. Curr Gastroenterol Rep. 2007; 9: 156-64. 